\title{
Iranian EFL Teachers' and Learners' Perspectives of Oral Error Correction: Does the Timeline of Correction Matter?
}

\author{
Las perspectivas de corrección de errores oral \\ de profesores y alumnos del inglés iraníes: \\ ¿importa la línea de tiempo de la corrección?
}

\begin{tabular}{c}
\hline Ali Akbar FARAHANI \\
University of Tehran, Tehran, Iran \\
farahani@ut.ac.ir \\
\hline
\end{tabular}

Soory SALAJEGHEH
University of Tehran, Tehran, Iran
s.khezrlou@gmail.com

\begin{abstract}
Although the provision of error correction is common in education, there are controversies regarding 'when' correction is most effective and why it is effective. This study investigated the differences between Iranian English as a foreign language (EFL) teachers and learners regarding their perspectives towards the timeline of error correction in the speaking skill. Two main categories of immediate and delayed feedback types were determined, with the immediate category specifically referring to 'very soon' and 'after speaking' and the delayed one relating to 'after activities' and 'end of class' sub-categories. To empirically test the hypothesis behind the study, a total of 460 teachers and learners were invited to complete Fukuda's questionnaire. The data obtained were analysed through multivariate analysis of variance (MANOVA), the results of which showed teachers' preferences for immediate correction while the learners' inclined towards delayed correction. Based on these results, specific properties and circumstances in relation to the timing of feedback are proposed to enhance its efficiency in language classrooms.
\end{abstract}

Keywords: Error correction; timeline of correction; immediate correction; delayed correction.

\section{Resumen}

Aunque la prestación de corrección de errores es común en la educación, existen controversias en cuanto a 'cuándo' la corrección es más eficaz y por qué es eficaz. Este estudio investigó las diferencias entre profesores y alumnos del inglés como lengua extranjera(EFL) iraníes con respecto a sus perspectivas hacia la línea de tiempo de la corrección de errores en la habilidad de hablar. Se determinaron 2 categorías principales de tipos de retroalimentación, inmediatos y retardados, con la categoría inmediata refiriéndose específicamente a 'muy pronto' y 'después de hablar' y la retardada en relación con las sub-categorías 'después de las actividades' y 'al final de la clase'. Para probar empíricamente la hipótesis detrás del estudio, se invitaron a un total de 460 profesores y alumnos para completar el cuestionario de Fukuda. Los datos obtenidos fueron analizados mediante un análisis multivariado de varianza (MANOVA), cuyos resultados mostraron las preferencias de los profesores para la corrección inmediata, mientras que los estudiantes se inclinan hacia la corrección retardada. Con base en estos resultados, se proponen las propiedades y las circunstancias específicas en relación con el momento de la retroalimentación para mejorar su eficiencia en las aulas de idiomas.

Palabras clave: corrección de errores; línea de tiempo de la corrección; corrección inmediata; corrección retardada.

Received: 2015-02-13 / Sent for peer review: 2015-02-13 / Accepted bypeers: 2015-06-12 / Approved: 2015-06-13

To reference this article / Para citar este artículo

Farahani, A. A. \& Salajegheh, S. (2015). Iranian EFL teachers' and learners' perspectives of oral error correction: Does the timeline of correction matter? Latin American Journal of Content and Language Integrated Learning, 8(2), 184-211. doi:10.5294/laclil.2015.8.2.6 


\section{INTRODUCTION}

According to Chaudron (1977), error correction (EC) is a reaction of teachers that demands progress in the students' communicative competences. Student errors should be considered and handled in the class because of their great importance. Linguistic correction includes correction of pronunciation and grammar; sociolinguistic correction includes body language and tone of voice; it is more important than linguistic correction (Mendelson, 1990). The issue of EC is complicated. Sometimes the students do not use problematic structures because they are trying to avoid making errors (Brown, 2000); this is called the avoidance strategy. However, students need to know that EC can benefit their abilities to notice grammatical structures and the gap between what they want to say and what they can say (Kim, 2004; Swain, 1995).

In the process of language learning, and especially in the process of EC, learners are especially important; however, their importance was seldom considered until after the 1960s. Today, it is widely believed that teachers should adopt a teaching methodology that accepts the central role of learners and, as a result, they should become more familiar with their students' learning styles and attitudes as the appropriateness of EC would depend largely on these (Ellis, 2007; Firwana, 2001). Research points to the fact that students have a strong preference for EC and welcome its practice in the classroom (Katayama, 2007; Timson, Grow, \& Matsuoka, 1999).

Nevertheless, recognizing the differences between teacher and student opinions on EC is a controversial issue in the teaching and learning process. Students' attitudes toward the type and success of EC can affect their progress (Schulz, 2001). If students' and teachers' expectations about EC can converge, then teachers would have a better chance to guide their students to successful language learning; otherwise, the mismatches can provide dissatisfaction (Brown, 2009; MacIntyre \& Gardner, 1994). 


\section{TIMELINE OF ERROR CORRECTION}

One of the most critical aspects of feedback provision, which has often led to differing opinions between teachers and learners, is the time at which it is provided-in other words, how long after an error is committed the learner is corrected. The literature on this issue broadly classifies time of feedback into two classifications: 1) immediate or instant feedback, where the student is corrected as soon as he/she commits an error, and 2) delayed feedback, where the feedback is postponed to a later time, so as to allow the student to finish his or her message first. Numerous psychologists have long supported immediate feedback. Skinner (1954, as cited in Richards \& Rodgers, 1986) can be considered as one of the pioneers in this regard. Skinner is considered the founder of behavioral psychology, which in turn formed the basis of audio-lingual method (ALM) of language learning. The theory of learning underlying ALM, an anti-mentalist view, was that learners could learn a language more effectively if they acquired good habits by giving correct responses rather than by making mistakes. By memorizing dialogues and performing pattern drills, the chance of producing mistakes could be minimized (Richards \& Rodgers, 1986). Based on the ALM theory of learning, language is habit formation; thus, errors must be prevented and corrected by the teacher at all costs to avoid formation of bad habits. Based on this theory, then, Skinner argued that immediate feedback could act as a reinforcer for correct responses. Since then, many other researchers have likewise valued the positive effects associated with immediate feedback as a reinforcer.

Yet although (as discussed above) there seem to be some advantages associated with immediate feedback, other researchers have argued that delayed feedback can be more helpful than the immediate feedback type (e.g., Nakata, 2014; Rolin-Ianziti, 2010). Delayed feedback supporters believe that its efficiency results from the delayed retention effect, according to which learners who are given feedback after a delay retain and recall more than those who are given immediate feedback (Kulhavy, Yekovich, 
\& Dyer, 1977; Schroth \& Lund, 1993). According to these proponents, the delayed retention effect takes place because:

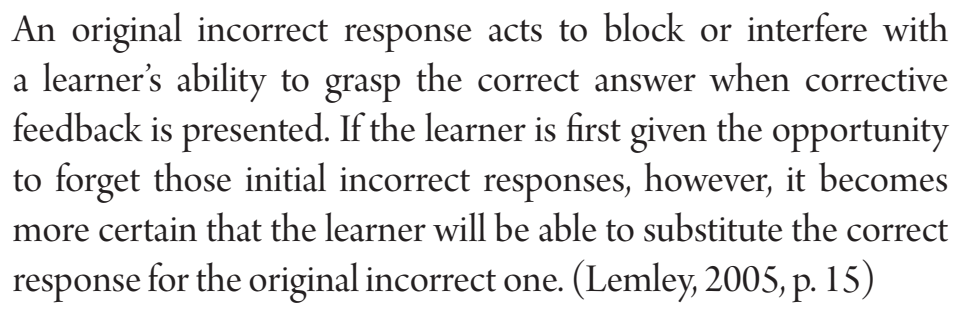

However, as stated previously, opinions and experiences differ. For example, Allan (1991) argues that if the appropriate time for EC is missed, the correction can be harmful; on the other hand, Hendrickson (1978) contends that nobody can say what time is the best time for EC, while Lyster and Ranta (1997) emphasize that initiated repairs are important for students when they commit errors. Initiated repairs can help students consolidate knowledge and guide them to revise their hypotheses.

Although views differ regarding the time of error correction, the basic belief accepted by all is that correction that breaks the stream of speech should be avoided. In other words, learners should be given the opportunity to continue their communication even if some errors emerge. However, errors that do not damage the flow of conversation can be corrected, or the teacher (or any other source of correction) can implicitly direct the student's attention toward errors so as to avoid possible fossilization.

In line with the abovementioned arguments, the assumption in this study is that the timeline for error correction constitutes a fairly significant issue and needs to be addressed closely in the foreign language teaching/learning context. This concern becomes more complicated and fundamental when the differing opinions and preferences of teachers and learners come into play. Therefore, the present study examined Iranian EFL learners' and teachers' beliefs about the time of correction. The two broad categories of immediate 
and delayed error correction were examined with the immediate one being divided into 'very soon' and 'after speaking' and the delayed one divided into 'after activities' and 'end of class'.

Therefore, in the present study, the following research question and sub-questions were posed:

- $\quad$ Are there any significant differences between Iranian male and female teachers and adult EFL learners' preferences for times of corrective feedback in Kerman Jahad Daneshgahi Institute?

- Are there any significant differences between Iranian male and female teachers and adult EFL learners' preferences for immediate corrective feedback in Kerman Jahad Daneshgahi Institute?

- Are there any significant differences between Iranian male and female teachers and adult EFL learners' preferences for delayed corrective feedback after in Kerman Jahad Daneshgahi Institute?

\section{METHOD}

\section{Participants}

The participants of this study were both Iranian foreign language teachers and Iranian adult EFL learners at the Jahad Daneshgahi Institute in Kerman, Iran. The total number of the participants was 460 . The research setting included five English language institutes (I) and a French language institute. Participating in the were 101 (23.5\%) learners in I1, 24 (5.6\%) learners in I2, 143 (33.3\%) learners in I3, 103 (24.0\%) learners in I4, 26 (6.1\%) learners in I5 and 32 (7.5\%) learners in I6.

\section{Learners}

There were a total of 429 learners (see Table 1 ), both male and female. Their ages ranged from 18 to 60 years old, with $65.7 \%$ of them being adolescents and $34.3 \%$ adults. There were 161 (37.5\%) males and $268(62.5 \%)$ females, dividing them according to gender. Their native 
language was uniformly Persian, and the foreign language being learned was either English (92.5\%) or French (7.5\%). Learners' learning experience varied from 1 year (38.2\%), to 2-5 years (38\%), to 6-9 years (13.8\%), to more than 10 years (10\%); levels of proficiency also varied: beginners $(17 \%)$, lower-intermediate $(17 \%)$, intermediate $(45.7 \%)$, upper-intermediate (12.6\%) and advanced (7.7\%).

\section{Teachers}

A total of 31 teachers participated in the present study (see Table 2). Classified according to gender, 12 (38.7\%) were males and 19 (61.3\%) were females. Their ages ranged between 25 to 40 years old, with $34.5 \%$ adolescent and $65.5 \%$ adult teachers. Their teaching experience ranged from 1 year $(6.5 \%)$, to $2-5$ years $(54.8 \%)$, to 6-9 years $(29 \%)$, to more than 10 years $(9.7 \%)$. More specifically, with regard to oral skill teaching experience, this ranged from 1 year (9.7\%), to $2-5$ years $(61.3 \%)$, to $6-9$ years $(22.6 \%)$, to more than 10 years $(6.4 \%)$.

All the teachers should have passed several examinations in language skills to become teachers in the JD language institutes. They should have had at least a TOEFL, IELTS, or TESOL certificate, and should have been instructed in the teacher-training course (T.T.C.).

Table 1. Demographic characteristics of student participants

\begin{tabular}{|c|c|c|c|c|}
\hline $\begin{array}{c}\text { Age } \\
(\%)\end{array}$ & $\begin{array}{c}\text { Gender } \\
(\%)\end{array}$ & $\begin{array}{c}\text { Target } \\
\text { language } \\
(\%)\end{array}$ & $\begin{array}{c}\text { Years of } \\
\text { learning } \\
(\%)\end{array}$ & $\begin{array}{c}\text { Level of proficiency } \\
(\%)\end{array}$ \\
\hline $\begin{array}{c}\text { Adolescents } \\
(65.7)\end{array}$ & $\begin{array}{c}\text { Females } \\
(62.5)\end{array}$ & $\begin{array}{c}\text { English } \\
(92.5)\end{array}$ & $\begin{array}{c}1 \text { year } \\
(38.2)\end{array}$ & Beginners (17) \\
\hline $\begin{array}{c}\text { Adults } \\
(34.3)\end{array}$ & $\begin{array}{c}\text { Males } \\
(37.5)\end{array}$ & $\begin{array}{c}\text { French } \\
(7.5)\end{array}$ & $\begin{array}{c}2-5 \text { years } \\
(38)\end{array}$ & Lower-intermediate (17) \\
\hline \multicolumn{1}{|c|}{} & $\begin{array}{c}6-9 \text { years } \\
(13.8)\end{array}$ & Intermediate (45.7\%) \\
\cline { 4 - 5 } & & $\begin{array}{c}\text { More than } \\
10 \text { years } \\
(10)\end{array}$ & $\begin{array}{c}\text { Upper-intermediate (12.6) } \\
\text { Advanced (7.7) }\end{array}$ \\
\hline
\end{tabular}


Table 2. Demographic characteristics of teacher participants.

\begin{tabular}{|c|c|c|c|}
\hline $\begin{array}{c}\text { Age } \\
(\%)\end{array}$ & $\begin{array}{c}\text { Gender } \\
(\%)\end{array}$ & $\begin{array}{c}\text { Years of teaching } \\
(\%)\end{array}$ & $\begin{array}{c}\text { Oral skill teaching } \\
\text { experience } \\
(\%)\end{array}$ \\
\hline $\begin{array}{c}\text { Adolescents } \\
(34.5)\end{array}$ & $\begin{array}{c}\text { Females } \\
(61.3)\end{array}$ & 1 year (6.5) & 1 year $(9.7)$ \\
\hline Adults (65.5) & $\begin{array}{c}\text { Males } \\
(38.7)\end{array}$ & $2-5$ years (54.8) & $2-5$ years (61.3) \\
\hline & & $6-9$ years (29) & $6-9$ years $(22.6)$ \\
\cline { 2 - 4 } & $\begin{array}{c}\text { More than 10 years } \\
(9.7)\end{array}$ & $\begin{array}{c}\text { More than 10 years } \\
(6.4)\end{array}$ \\
\hline
\end{tabular}

\section{Instrument}

The present study employed Fukuda's (2004) preferences for error correction questionnaire, with one variant developed for the teachers $(\mathrm{N}$ of Items $=25)$ (see Appendix A: Questionnaire form for teachers) and another for the learners ( $\mathrm{N}$ of Items $=26$ ) (see Appendix B: Translated students' questionnaire form). Both questionnaires had seven sections, with the last of these obtaining demographic information about the participants. The sixth section consisted of 22 items that were aimed at exploring the teachers' / students' judgments about the giving and receiving of spoken error correction, frequency of giving and receiving spoken error correction, time of spoken error correction, types of errors that should be corrected, types of spoken error correction, and sources for providing spoken error correction. In the present study, only the sections concerning the time of spoken error correction was considered. Each of questionnaire item was to be scored according to a 5-point Likert-scale, with the rankings 'strongly agree,' 'agree,' 'neutral', 'disagree,' 'strongly disagree'; or 'always', 'usually', 'sometimes', 'occasionally', 'never'; or 'very effective,' 'effective', 'neutral', 'ineffective', 'very ineffective'.

\section{RESULTS}

This study used survey-based research. Questionnaires were administered to the participants during their classroom time. The data gath- 
ered were then analyzed using the Statistical Package for the Social Sciences (SPSS) version 21. A significance level of $0.05(\mathrm{p}<0.05)$ was set. For the research questions, descriptive statistics including means and standard deviations and multivariate analysis of variance (MANOVA) were carried out.

The MANOVA was used to provide an answer to the research question, which was concerned with the times of error correction and any possible differences between the teachers' and learners' preferences in this regard. The results are shown in Table 3 and Table 4.

Table 3. Descriptive statistics results for preferred correction time

\begin{tabular}{|c|c|c|c|c|}
\hline & participants & Mean & Std. Deviation & $\mathrm{N}$ \\
\hline \multirow{3}{*}{ very soon (item 3) } & students & 2.67 & 1.209 & 428 \\
\cline { 2 - 5 } & teachers & 3.39 & 1.022 & 31 \\
\cline { 2 - 5 } & Total & 2.72 & 1.210 & 459 \\
\hline \multirow{3}{*}{ after speaking (item 4) } & students & 2.28 & 1.066 & 428 \\
\cline { 2 - 5 } & teachers & 2.10 & .908 & 31 \\
\cline { 2 - 5 } & Total & 2.27 & 1.056 & 459 \\
\hline \multirow{3}{*}{ end of class (item 6) } & students & 3.02 & 1.089 & 428 \\
\cline { 2 - 5 } & teachers & 2.42 & .992 & 31 \\
\cline { 2 - 5 } & Total & 2.98 & 1.093 & 459 \\
\cline { 2 - 5 } & students & 3.59 & 1.136 & 428 \\
\cline { 2 - 5 } & teachers & 3.68 & .945 & 31 \\
\hline
\end{tabular}

The results of the descriptive statistics show that while the learners preferred the spoken error correction 'after activities', their teachers believed that the corrections should be provided 'very soon'.

The results of MANOVA showed that there were significant differences between the teachers' and learners' preferences only in the 'very soon' ( $F=10.34, p<0.001)$ and 'after activities' $(F=8.91, p<$ 0.003 ) items, with the teachers' preferences for 'very soon' but their learners' preferred 'after activities' as the best times for providing spoken error correction. 
Table 4. MANOVA results for the correction time

\begin{tabular}{|c|c|c|c|c|c|c|c|}
\hline Source & $\begin{array}{l}\text { Dependent } \\
\text { Variable }\end{array}$ & $\begin{array}{l}\text { Type III Sum } \\
\text { of Squares }\end{array}$ & $\mathrm{df}$ & $\begin{array}{l}\text { Mean } \\
\text { Square }\end{array}$ & $\mathrm{F}$ & Sig. & $\begin{array}{c}\text { Partial Eta } \\
\text { Squared }\end{array}$ \\
\hline \multirow{4}{*}{$\begin{array}{l}\text { Corrected } \\
\text { Model }\end{array}$} & very soon & $14.841 \mathrm{a}$ & 1 & 14.841 & 10.341 & .001 & .022 \\
\hline & $\begin{array}{c}\text { after } \\
\text { speaking }\end{array}$ & $.999 b$ & 1 & .999 & .896 & .344 & .002 \\
\hline & $\begin{array}{c}\text { after } \\
\text { activities }\end{array}$ & $10.464 c$ & 1 & 10.464 & 8.916 & .003 & .019 \\
\hline & end of class & $.215 d$ & 1 & .215 & .170 & .680 & .000 \\
\hline \multirow{4}{*}{ Intercept } & very soon & 1060.724 & 1 & 1060.724 & 739.057 & .000 & .618 \\
\hline & $\begin{array}{c}\text { after } \\
\text { speaking }\end{array}$ & 554.420 & 1 & 554.420 & 497.290 & .000 & .521 \\
\hline & $\begin{array}{c}\text { after } \\
\text { activities }\end{array}$ & 855.562 & 1 & 855.562 & 728.974 & .000 & .615 \\
\hline & end of class & 1527.170 & 1 & 1527.170 & $1.207 \mathrm{E} 3$ & .000 & .725 \\
\hline \multirow{4}{*}{ participants } & very soon & 14.841 & 1 & 14.841 & 10.341 & .001 & .022 \\
\hline & $\begin{array}{c}\text { after } \\
\text { speaking }\end{array}$ & .999 & 1 & .999 & .896 & .344 & .002 \\
\hline & $\begin{array}{c}\text { after } \\
\text { activities }\end{array}$ & 10.464 & 1 & 10.464 & 8.916 & .003 & .019 \\
\hline & end of class & .215 & 1 & .215 & .170 & .680 & .000 \\
\hline \multirow{4}{*}{ Error } & very soon & 655.904 & 457 & 1.435 & & & \\
\hline & $\begin{array}{c}\text { after } \\
\text { speaking }\end{array}$ & 509.502 & 457 & 1.115 & & & \\
\hline & $\begin{array}{c}\text { after } \\
\text { activities }\end{array}$ & 536.359 & 457 & 1.174 & & & \\
\hline & end of class & 578.220 & 457 & 1.265 & & & \\
\hline \multirow{4}{*}{ Total } & very soon & 4064.000 & 459 & & & & \\
\hline & $\begin{array}{c}\text { after } \\
\text { speaking }\end{array}$ & 2876.000 & 459 & & & & \\
\hline & $\begin{array}{c}\text { after } \\
\text { activities }\end{array}$ & 4624.000 & 459 & & & & \\
\hline & end of class & 6517.000 & 459 & & & & \\
\hline \multirow{4}{*}{$\begin{array}{l}\text { Corrected } \\
\text { Total }\end{array}$} & very soon & 670.745 & 458 & & & & \\
\hline & $\begin{array}{c}\text { after } \\
\text { speaking }\end{array}$ & 510.501 & 458 & & & & \\
\hline & $\begin{array}{c}\text { after } \\
\text { activities }\end{array}$ & 546.824 & 458 & & & & \\
\hline & end of class & 578.436 & 458 & & & & \\
\hline
\end{tabular}

Notes:
a. $\quad$ R Squared $=0.022$ (Adjusted R Squared $=0.020$ ).
b. $\quad$ R Squared $=0.002$ (Adjusted R Squared $=0.000$ ).
c. $\quad$ R Squared $=0.019$ (Adjusted R Squared $=0.017$ ).
d. R Squared $=0.000$ (Adjusted R Squared $=-0.002$ ). 


\section{DISCUSSION}

The results from performing MANOVA analysis of data indicated significant differences between teachers and learners: while learners preferred EC be done at the end of the activities, teachers were proponents of immediate correction. This finding is also consistent with the results of other studies, showing that learners wish to save face during the conversation, while teachers try to provide solutions through immediate correction (Mendez, 2010).

Errors can work like signals that show language learning is taking place (Hendrickson, 1978; Ziahosseiny, 2005). Errors show which parts of lesson have been understood and what parts need to be revised (Hedge, 2000). Most errors are developmental errors (Dulay \& Burt, 1974), reflecting signs of learning. To put it another way, errors are necessary, since they illuminate students' testing of hypotheses (Corder, 1981). Errors are, therefore, important and should be taken into consideration by classroom teachers (Brown, 2000). When teachers provide EC to students, and the students answer immediately, this is representative of uptake; it may be necessary to repair the uptake again, or it may be in the correct form (Lyster \& Ranta, 1997). Certain factors, such as teaching context and types of correction, affect the production of uptake (Ellis, Basturkmen, \& Lowen, 2001). Through systematic observation, a number of common patterns can be found for giving correction and observing an appropriate uptake (Chaudron, 1977). Elicitation, repetition, metalinguistic, and clarification requests have been observed in correlation with appropriate uptake (Mackey, Gass, \& McDonough, 2000).

Several studies have been conducted to examine the effect of timing on EC, especially the immediate correction done by the teachers, which can predict uptake (Loewen, 2004). In repetitions, clarification, elicitation and metalinguistic requests, the focus is exclusively on form and immediate correction by peer and self-repair (Lyster \& Ranta, 1997; Rolin-Ianziti, 2006). Intention can be significantly enhanced 
by immediate correction (Brosvic, Epstein, Cook, \& Dihoff, 2005). Immediate repair can also be advantageous for phonological errors when students follow repetitions and recasts (Lyster, 1998). Many teachers and their students who follow the audio-lingual method still prefer immediate correction (Bartram \& Walton, 1991). In the audiolingual method, immediate correction is provided because it is based on the idea of habit formation (Larsen-Freeman, 2014). However, not all errors should necessarily be corrected immediately (Nunan \& Lamb, 1996). Research has shown that immediate correction is preferred by $30 \%$ of students (Lewis, 2005); however, depending on the type of skill and the time of communication, immediate correction can be either helpful or harmful. For instance, it has been found that immediate correction can interrupt communication and inhibit the willingness of students to speak (Hendrickson, 1978). Thus, it may be better to postpone correction to, instead of during conversation, to the end of a class.

With delayed correction, teachers can review errors before giving students the opportunity to respond to correction (Lyster \& Ranta, 1997). Delayed correction provides an opportunity for teachers and students to complete the negotiation of meaning before engaging in the negotiation of form (Rolin-Lanziti, 2006). In laboratory settings, delayed correction has been shown to be more beneficial (Brosvic, Epstein, Cook, \& Dihoff, 2005). Destroying communication to correct errors would not be logical. EC should be postponed until the end of the interaction (Ellis, 2005) since, when the purpose is communication, EC should be delayed (Kelly, 2006). Prior research has also shown the helpfulness of delayed correction in certain cases by showing that students prefer delayed correction as a way of protecting their confidence (Lenon, 1991; Lewis, 2005; Salikin, 2001).

\section{Implications}

The outcomes of the present study should be beneficial for the teachers since, much of the time, teachers are unfamiliar with students' wants, 
or their own coworkers' preferences, and perform based on their suppositions. In such cases, in spite of teachers' best efforts, their students may not be satisfied with the results, which may be less than delightful for either themselves or their teachers. Teachers should be aware of their students' and other teachers' opinions, investigate the similarities and dissimilarities, and take these preferences into consideration so as to act in a way that results in more satisfaction and success.

The results of the present study should also be beneficial for learners. Most of the time, students do not know how to act effectively in the language classroom-especially in group conversation activities, because they do not recognize their teachers' specificities or other students' beliefs. Yet by recognizing their teachers' estimations, students can learn to respect their teachers' intentions. By being more aware of others' opinions in their learning spaces (as well as attending class diligently, participating attentively in learning exercises, listening more seriously), they can gain better results.

\section{REFERENCES}

Allan,D. (1991). Tapejournal: Bridging the gap between communication and correction. English Teaching Journal, 45, 56-72.

Bartram, M. \& Walton, R. (1991). Correction. New York, NY: Language Teaching Publications.

Brosvic, G. M., Epstein, M. L., Cook, M. J. \& Dihoff, R. E. (2005). Efficacy of error for the correction of initially incorrect assumptions and of feedback for the affirmation of correct responding. The Psychological Record, 55(3), 401-418.

Brown, A. (2009). Students' and teachers' perceptions of effective foreign language teaching: A comparison of ideals. The Modern Language Journal, 93, 46-60.

Brown, H. D. (2000). Principle of language learning and teaching. White Plains, NY: Addison Wesley Longman. 
Chaudron, C. (1977). A descriptive model of discourse in the corrective treatment of learners' errors. Language Learning, 27, 29-46.

Corder, S. P. (1981). Error analysis and interlanguage. Oxford, UK: Oxford University Press.

Dulay, H. \& Burt, M. (1974). Errors and strategies in child second language acquisition. TESOL Quarterly, 8, 129-136.

Ellis, R. (2005). Analyzing learner language. Oxford, UK: Oxford University Press.

Ellis, R. (2007, May). Corrective feedback in theory, research and practice. Paper presented at the 5th International Conference on ELT in China \& The 1st Congress of Chinese Applied Linguistics, Beijing Foreign Language Studies University, Beijing, China. Retrieved from http://www.celea.org.cn/2007/keynote/ppt/ Ellis.pdf

Ellis, R., Basturkmen, H. \& Lowen, S. (2001). Learner uptake in communicative ESL lessons. Language Learning, 51(2), 281-318. Firwana, S. S. (2011). A comparison between Palestinian EFL teachers' and students' attitudes toward oral error and their correction. The Journal of the Islamic University of Gaza (Humanities Research Series), 19(2), 1527-1558. Retrieved from http://resportal. iugaza.edu.ps/articles/\%D8\%B5\%D8\%A7\%D8\%AF\%D9\%82 \%D9\%81\%D8\%B1\%D9\%88\%D8\%A7\%D9\%86\%D8\%A9.pdf Fukuda, Y. (2004). Treatment of spoken errors in Japanese high school oral communication classes (Unpublished Master's thesis). California State University, San Francisco, CA.

Hedge, T. (2000). Teaching and learning in the language classroom. Oxford, UK: Oxford University Press.

Hendrickson, J. (1978). Error correction in foreign language teaching: Recent theory, research, and practice. Modern Language Journal, $62,387-398$.

Katayama, A. (2007). Learners' perceptions toward oral error correction. In K. Bradford- Watts (Ed.), JALT 2006 Conference Proceedings (pp. 34-42). Tokyo, Japan: JALT. 
Kelly, S. (2006). Error correction. English Language Centre, 17, 68-107. Kim, J. H. (2004). Issues of corrective feedback in second language acquisition. Working Papers in TESOL \& Applied Linguistics, 4(2), 1-24.

Kulhavy, R. W., Yekovich, F. R. \& Dyer, J. W. (1977). Feedback and response confidence. Journal of Educational Psychology, 68(5), $522-528$.

Larsen-Freeman, D. (2014). Teaching grammar. In M. Celce-Murcia, D. Brinton, \& M.A. Snow (Eds.), Teaching English as a second or foreign language ( $4^{\text {th }}$ ed.) (pp. 256-270). Boston, MA: National Geographic Learning/Cengage Learning.

Lemley, D. C. (2005). Delayed versus immediate feedback in an independent study high school setting (Unpublished doctoral dissertation). Brigham Young University, Provo, UT.

Lennon, P. (1991). Error: Some problems of definition, identification and distinction. Applied Linguistics, 12, 33-62.

Lewis, M. (2005). Role of self-correction in learning ESP. ESP World, 20(3), 72-84.

Loewen, S. (2004). Uptake in incidental focus on form in meaningfocused ESL lessons. Language Learning, 54(1), 153-188.

Lyster, R. (1998). Negotiation of form, recasts, and explicit correction in relation to error types and learner repair in immersion classrooms. Language Learning Journal, 42(2), 183-218.

Lyster, R. \& Ranta, L. (1997). Corrective feedback and learner uptake: Negotiation of form in communicative classrooms. Studies in Second Language Acquisition, 19, 37-66.

Mackey, A., Gass, S. \& McDonough, K. (2000). How do learners perceive interactional feedback? Studies in Second Language Acquisition, 22(4), 471-497.

MacIntyre, P., \& Gardner, R. (1994). The subtle effects of induced anxiety on cognitive processing in the second language. Language Learning, 44, 283-305. 
Mendelson, D. (1990). How to correct errors in the communicative language talking class. Prospect, 5(1), 67-83.

Mendez, E. H. (2010). Oral corrective feedback: Some ways to go about it. FEL, 2(1), 25-38.

Nakata, T. (2014). Effects of feedback timing on second language vocabulary learning: Does delaying feedback increase learning? Language Teaching Research, 7, 23-42.

Nunan, D. \& Lamb, C. (1996). The self-directed teacher: Managing the learning process. Cambridge, UK: Cambridge University Press.

Richards, J. C. \& Rodgers, T. (1986). Approaches and methods in language teaching: A description and analysis. Cambridge, $\mathrm{UK}$ : Cambridge University Press.

Rolin-Ianziti, J. C. (2006). Teacher corrective practices in the foreign language classroom: The effect of timing. In C. Hopkinson \& C. Hall, Social change in the $21^{\text {st }}$ Century 2006 Conference Proceedings, Queensland University of Technology, Carseldine Campus, Brisbane, Australia, 27 October, 2006 (pp. 1-14). Brisbane, Australia: Centre for Social Change Research, Queensland University of Technology. Retrieved from http://eprints.qut. edu.au/6898/1/6898.pdf

Rolin-Ianziti, J. (2010). The organization of delayed second language correction. Language Teaching Research, 14(2), 183-206.

Salikin, H. (2001). Learner's perception of oral error correction: An interpretive study. JIBS (Jurnal Ilmu Bahasa dan Sastra), 1(2), 103-129.

Schulz, R. A. (2001). Cultural differences in student and teacher perceptions concerning the role of grammar instruction and corrective feedback: USA-Colombia. The Modern Language Journal, 85(2), 244-258. 
Schroth, M. L., \& Lund, E. (1993). Role of delay of feedback on subsequent pattern recognition transfer tasks. Contemporary Educational Psychology, 18, 15-22.

Swain, M. (1995). The output hypothesis: Just speaking and writing are not enough. The Canadian Modern Language Review, 50, 158-164. Timson, S., Grow, A., \& Matsuoka, M. (1999). Error correction preferences of second language learners: A Japanese perspective. The Japan Association of College English Teachers (JACET) Bulletin, 30, 135-147.

Ziahosseiny, S. M. (2005). A contrastive analysis of Persian and English \& error analysis. Tehran, Iran: Nashr-e Vira. 


\section{APPENDICES}

\section{Appendix A Teacher Questionnaire}

Questionnaire Form for Teacher

Data collected from this anonymous survey will be used for completion of a master's degree in Teaching English to Speakers OfOther Languages at Sacramento State University. The information gathered will be used for research on corrective feedback in language classrooms. The purpose of this study is to investigate the opinions of teachers and students about error correction. There are no risks or benefits to you from participating in this research.

Please do not put your name on this questionnaire.

Please circle the information that applies to you. Make sure to mark only one.

1. Students' spoken errors should be treated.

\begin{tabular}{|c|c|c|c|c|}
\hline $\begin{array}{c}\text { Strongly } \\
\text { Agree }\end{array}$ & Agree & Neutral & Disagree & $\begin{array}{c}\text { Strongly } \\
\text { Disagree }\end{array}$ \\
\hline
\end{tabular}

2. How often do you give corrective feedback on students' spoken errors?

\begin{tabular}{|c|c|c|c|c|}
\hline $\begin{array}{c}\text { Always } \\
(100 \%)\end{array}$ & $\begin{array}{c}\text { Usually } \\
(80 \%)\end{array}$ & $\begin{array}{c}\text { Sometimes } \\
(50 \%)\end{array}$ & $\begin{array}{c}\text { Occasionally } \\
(20 \%)\end{array}$ & $\begin{array}{c}\text { Never } \\
(0 \%)\end{array}$ \\
\hline
\end{tabular}

Students' spoken errors should be treated at the following time.

3. As soon as errors are made even if it interrupts the student's speaking.

\begin{tabular}{|c|c|c|c|c|}
\hline $\begin{array}{c}\text { Strongly } \\
\text { Agree }\end{array}$ & Agree & Neutral & Disagree & $\begin{array}{c}\text { Strongly } \\
\text { Disagree }\end{array}$ \\
\hline
\end{tabular}


4. After the student finishes speaking.

\begin{tabular}{|c|c|c|c|c|}
\hline $\begin{array}{c}\text { Strongly } \\
\text { Agree }\end{array}$ & Agree & Neutral & Disagree & $\begin{array}{c}\text { Strongly } \\
\text { Disagree }\end{array}$ \\
\hline
\end{tabular}

5. After the activities.

\begin{tabular}{|c|c|c|c|c|}
\hline $\begin{array}{c}\text { Strongly } \\
\text { Agree }\end{array}$ & Agree & Neutral & Disagree & $\begin{array}{c}\text { Strongly } \\
\text { Disagree }\end{array}$ \\
\hline
\end{tabular}

6. At the end of class.

\begin{tabular}{|c|c|c|c|c|}
\hline $\begin{array}{c}\text { Strongly } \\
\text { Agree }\end{array}$ & Agree & Neutral & Disagree & $\begin{array}{c}\text { Strongly } \\
\text { Disagree }\end{array}$ \\
\hline
\end{tabular}

How often do you treat each of the following types of errors in oral communication classes?

7. Serious spoken errors that cause a listener to have difficulty understanding the meaning of what is being said.

\begin{tabular}{|c|c|c|c|c|}
\hline $\begin{array}{c}\text { Always } \\
(100 \%)\end{array}$ & $\begin{array}{c}\text { Usually } \\
(80 \%)\end{array}$ & $\begin{array}{c}\text { Sometimes } \\
(50 \%)\end{array}$ & $\begin{array}{c}\text { Occasionally } \\
(20 \%)\end{array}$ & $\begin{array}{c}\text { Never } \\
(0 \%)\end{array}$ \\
\hline
\end{tabular}

8. Less serious spoken errors that do not cause a listener to have difficulty understanding the meaning of what is being said.

\begin{tabular}{|c|c|c|c|c|}
\hline $\begin{array}{c}\text { Always } \\
(100 \%)\end{array}$ & $\begin{array}{c}\text { Usually } \\
(80 \%)\end{array}$ & $\begin{array}{c}\text { Sometimes } \\
(50 \%)\end{array}$ & $\begin{array}{c}\text { Occasionally } \\
(20 \%)\end{array}$ & $\begin{array}{c}\text { Never } \\
(0 \%)\end{array}$ \\
\hline
\end{tabular}

9. Frequent spoken errors.

\begin{tabular}{|c|c|c|c|c|}
\hline $\begin{array}{c}\text { Always } \\
(100 \%)\end{array}$ & $\begin{array}{c}\text { Usually } \\
(80 \%)\end{array}$ & $\begin{array}{c}\text { Sometimes } \\
(50 \%)\end{array}$ & $\begin{array}{c}\text { Occasionally } \\
(20 \%)\end{array}$ & $\begin{array}{c}\text { Never } \\
(0 \%)\end{array}$ \\
\hline
\end{tabular}


10. Infrequent spoken errors.

\begin{tabular}{|c|c|c|c|c|}
\hline $\begin{array}{c}\text { Always } \\
(100 \%)\end{array}$ & $\begin{array}{c}\text { Usually } \\
(80 \%)\end{array}$ & $\begin{array}{c}\text { Sometimes } \\
(50 \%)\end{array}$ & $\begin{array}{c}\text { Occasionally } \\
(20 \%)\end{array}$ & $\begin{array}{c}\text { Never } \\
(0 \%)\end{array}$ \\
\hline
\end{tabular}

11. Individual errors made by only one student.

\begin{tabular}{|c|c|c|c|c|}
\hline $\begin{array}{c}\text { Always } \\
(100 \%)\end{array}$ & $\begin{array}{c}\text { Usually } \\
(80 \%)\end{array}$ & $\begin{array}{c}\text { Sometimes } \\
(50 \%)\end{array}$ & $\begin{array}{c}\text { Occasionally } \\
(20 \%)\end{array}$ & $\begin{array}{c}\text { Never } \\
(0 \%)\end{array}$ \\
\hline
\end{tabular}

How do you rate each type of spoken error correction below?

Teacher: Where did you go yesterday?

Student: I go to the park.

12. Could you say that again?

\begin{tabular}{|c|c|c|c|c|}
\hline Very Effective & Effective & Neutral & Ineffective & $\begin{array}{c}\text { Very } \\
\text { Ineffective }\end{array}$ \\
\hline
\end{tabular}

13. I go? (Repetition: The teacher emphasizes the student's grammatical error by changing his/her tone of voice.)

\begin{tabular}{|l|l|l|l|l|}
\hline Very Effective & Effective & Neutral & Ineffective & $\begin{array}{c}\text { Very } \\
\text { Ineffective }\end{array}$ \\
\hline
\end{tabular}

14. You went to the park yesterday? (Implicit feedback: The teacher does not directly point out the student's error but indirectly corrects it.)

\begin{tabular}{|l|l|l|l|c|}
\hline Very Effective & Effective & Neutral & Ineffective & $\begin{array}{c}\text { Very } \\
\text { Ineffective }\end{array}$ \\
\hline
\end{tabular}


15. "Go" is in the present tense. You need to use the past tense "went" here. (Explicit feedback: The teacher gives the correct form to the student with a grammatical explanation.

\begin{tabular}{|l|l|l|l|l|}
\hline Very Effective & Effective & Neutral & Ineffective & $\begin{array}{c}\text { Very } \\
\text { Ineffective }\end{array}$ \\
\hline
\end{tabular}

16. Yesterday, I.....(Elicitation: The teacher asks the student to correct and complete the sentence.)

\begin{tabular}{|l|l|l|l|l|}
\hline Very Effective & Effective & Neutral & Ineffective & $\begin{array}{c}\text { Very } \\
\text { Ineffective }\end{array}$ \\
\hline
\end{tabular}

17. Really? What did you do there? (No corrective feedback: The teacher does not give corrective feedback on the student's errors.)

\begin{tabular}{|l|l|l|l|l|}
\hline Very Effective & Effective & Neutral & Ineffective & $\begin{array}{c}\text { Very } \\
\text { Ineffective }\end{array}$ \\
\hline
\end{tabular}

18. How does the verb change when we talk about the past? (Metaliguistic feedback: The teacher gives a hint or a clue without specifically pointing out the mistake.)

\begin{tabular}{|l|l|l|l|c|}
\hline Very Effective & Effective & Neutral & Ineffective & $\begin{array}{c}\text { Very } \\
\text { Ineffective }\end{array}$ \\
\hline
\end{tabular}

19. I went to the park. (Recast: The teacher repeats the student's utterance in the correct form without pointing out the student's error.)

\begin{tabular}{|l|l|l|l|c|}
\hline Very Effective & Effective & Neutral & Ineffective & $\begin{array}{c}\text { Very } \\
\text { Ineffective }\end{array}$ \\
\hline
\end{tabular}

The following person should treat students' errors. 
20. Classmates

\begin{tabular}{|c|c|c|c|c|}
\hline $\begin{array}{c}\text { Strongly } \\
\text { Agree }\end{array}$ & Agree & Neutral & Disagree & $\begin{array}{c}\text { Strongly } \\
\text { Disagree }\end{array}$ \\
\hline
\end{tabular}

\section{Teachers}

\begin{tabular}{|c|c|c|c|c|}
\hline $\begin{array}{c}\text { Strongly } \\
\text { Agree }\end{array}$ & Agree & Neutral & Disagree & $\begin{array}{c}\text { Strongly } \\
\text { Disagree }\end{array}$ \\
\hline
\end{tabular}

\section{Students themselves}

\begin{tabular}{|c|c|c|c|c|}
\hline $\begin{array}{c}\text { Strongly } \\
\text { Agree }\end{array}$ & Agree & Neutral & Disagree & $\begin{array}{c}\text { Strongly } \\
\text { Disagree }\end{array}$ \\
\hline
\end{tabular}

\section{Demographics}

Please circle the information that applies to you. Make sure to mark only one.

\section{Gender}

\begin{tabular}{|c|c|}
\hline Male & Female \\
\hline
\end{tabular}

\section{How long have you been teaching English?}

\begin{tabular}{l|l|l|l}
1 year & $2-5$ years & $6-9$ years & More than 10 years
\end{tabular}

25. How long have you been teaching oral skill classes?

\begin{tabular}{|l|l|l|l|}
\hline 1 year & $2-5$ years & $6-9$ years & More than 10 years \\
\hline
\end{tabular}




\section{APPENDIX B}

\section{Student \\ Questionnaire}

Translated Students' Questionnaire Form

Data collected from this anonymous survey will be used for completion of a master's degree in Teaching English to Speakers Of Other Languages at Sacramento State University. The information gathered will be used for research on corrective feedback in language classrooms. The purpose of this study is to investigate the opinions of teachers and students about error correction. You could feel uncomfortable with some of the questions, but you may skip any question you prefer not to answer. There are no benefits to you from participating in this research.

Please do not put your name on this questionnaire.

لكفا اسم خود را روى اين برسشنامه ننويسيد.

Please circle the information that applies to you. Make sure to mark only one.

• • لطفا دور اطلاعاتى كه از شما تقاضا شده است دايره بكثيد. اطمينان حاصل كنيد كه فقط يك مورد را علامت بزنيد.

1. I want to receive corrective feedback (e.g., provide a hint for me to self-correct, tell me that I made an error, or correct my error.) when I make mistakes.

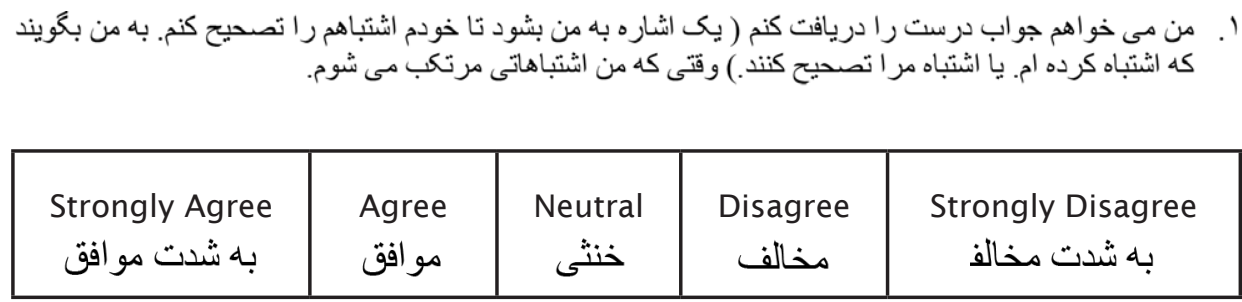


2. How often do you want your teacher to give corrective feedback on your spoken errors?

r. جند وقت به جند وقت شما مى خو اهيد كه معلمتان روى اشتباهات شفاهى شما جو اب درست را بدهد؟

\begin{tabular}{|c|c|c|c|c|}
\hline $\begin{array}{l}\text { Always } \\
\text { هيشاه } \\
\text { (100\%) }\end{array}$ & $\begin{array}{l}\text { Usually } \\
\text { لمعو } \\
\text { (80\%) }\end{array}$ & $\begin{array}{c}\text { Sometimes } \\
\text { بعضى وقتها (50\%) }\end{array}$ & $\begin{array}{l}\text { Occasionally } \\
\text { كاهى اوقات } \\
\text { (20\%) }\end{array}$ & $\begin{array}{l}\text { Never } \\
\text { هركر } \\
(0 \%)\end{array}$ \\
\hline
\end{tabular}

When do you want your spoken errors to be treated?

$$
\text { جه وقت شما مى خو اهيد اشتباهات شفاهى تان برطرف شود؟ }
$$

3. As soon as errors are made even if it interrupts my conversation. r. به محض اينكه اشتباهاتى صورت بكيرد حتى اكر مكالمه من را قطع مى كند.

\begin{tabular}{|c|c|c|c|c|}
\hline $\begin{array}{l}\text { Strongly Agree } \\
\text { بهدت موافق شوت }\end{array}$ & $\begin{array}{l}\text { Agree } \\
\text { مو افق }\end{array}$ & $\begin{array}{c}\text { Neutral } \\
\text { خنتى }\end{array}$ & $\begin{array}{c}\text { Disagree } \\
\text { مخالف }\end{array}$ & $\begin{array}{c}\text { Strongly Disagree } \\
\text { به شدت مخالف }\end{array}$ \\
\hline
\end{tabular}

\section{After I finish speaking.}

$$
\text { ع. . بعد از اينكه صحبتم را تمام كنم. }
$$

\begin{tabular}{|c|c|c|c|c|}
\hline $\begin{array}{l}\text { Strongly Agree } \\
\text { به شدت مو افق }\end{array}$ & $\begin{array}{l}\text { Agree } \\
\text { مو افق }\end{array}$ & $\begin{array}{c}\text { خنutral } \\
\text { ختىى }\end{array}$ & $\begin{array}{c}\text { Disagree } \\
\text { مخالف }\end{array}$ & $\begin{array}{l}\text { Strongly Disagree } \\
\text { به شدت مخالف }\end{array}$ \\
\hline
\end{tabular}

\section{After the activities.}

\begin{tabular}{|c|c|c|c|c|}
\hline $\begin{array}{l}\text { Strongly Agree } \\
\text { به شدت مو افق }\end{array}$ & $\begin{array}{l}\text { Agree } \\
\text { موافق }\end{array}$ & $\begin{array}{c}\text { Neutral } \\
\text { خنثى }\end{array}$ & $\begin{array}{c}\text { Disagree } \\
\text { مخالف }\end{array}$ & $\begin{array}{c}\text { Strongly Disagree } \\
\text { به شدت مخالف }\end{array}$ \\
\hline
\end{tabular}

0. بعد از فعاليتها.

\begin{tabular}{|c|c|c|c|c|}
\hline $\begin{array}{l}\text { Strongly Agree } \\
\text { به شدت مو افق }\end{array}$ & $\begin{array}{l}\text { Agree } \\
\text { مو افق }\end{array}$ & $\begin{array}{c}\text { Neutral } \\
\text { خنثى }\end{array}$ & $\begin{array}{l}\text { Disagree } \\
\text { مخالف }\end{array}$ & $\begin{array}{l}\text { Strongly Disagree } \\
\text { به شدت مخالف }\end{array}$ \\
\hline
\end{tabular}

\section{At the end of class.}


How often do you want each of the following types of errors to receive corrective feedback?

• جند وقت به جند وقت شما مى خو اهيد هر كدام از انو اع خطاهاى ذيل جواب صحيح را دريافت كنند؟

7. Serious spoken errors that may cause problems in a listener's understanding.

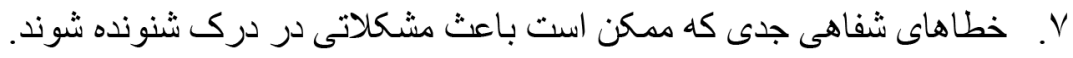

\begin{tabular}{|c|c|c|c|c|}
\hline Always & Usually & Sometimes & Occasionally & Never \\
\hline هميشه & معمو لا & بعضى وقتها & كاهى اوقات & هركز \\
\hline (100\%) & (80\%) & $(50 \%)$ & (20\%) & (0\%) \\
\hline
\end{tabular}

8. Less serious spoken errors that do not affect a listener's understanding.

^. خطاهاى شفاهى كه خيلى جدى نيستند و در درك شنونده اثر نمى كذارد.

\begin{tabular}{|c|c|c|c|c|}
\hline Always & Usually & Sometimes & Occasionally & Never \\
\hline هميشه & معمو لا & بعضى وقتها & كَاهى اوقات & هركز \\
\hline (100\%) & (80\%) & (50\%) & (20\%) & (0\%) \\
\hline
\end{tabular}

9. Frequent spoken errors.

9 . اثشتباهات شفاهى كه فر اوان اتفاق مى افتند.

\begin{tabular}{|c|c|c|c|c|}
\hline Always & Usually & Sometimes & Occasionally & Never \\
\hline هميشه & معمو لا & بعضى وقتها & كاهى اوقات & هركز \\
\hline (100\%) & (80\%) & (50\%) & (20\%) & (0\%) \\
\hline
\end{tabular}

\section{Infrequent spoken errors.}

• 1 . اشتباهات شفاهى كه فر اوان اتفاق نمى افتند و نادر هستند.

\begin{tabular}{|c|c|c|c|c|}
\hline Always & Usually & Sometimes & Occasionally & Never \\
\hline هميشه & معمو لا & بعضى وقتها & كاهى اوقات & هركز \\
\hline (100\%) & (80\%) & (50\%) & (20\%) & (0\%) \\
\hline
\end{tabular}


11. My individual errors (i.e., errors that other students may not make.)

1 ( اشتباهات فردى خودم (اشتباهاتى كه ديكر دانش آموز ان مدكن است مرتكب نشوند.)

\begin{tabular}{|c|c|c|c|c|}
\hline Always & Usually & Sometimes & Occasionally & Never \\
\hline هميشه & معمولا & بعضى وقتها & كاهى اوقات & هركز \\
\hline (100\%) & (80\%) & (50\%) & (20\%) & (0\%) \\
\hline
\end{tabular}

\section{How would you rate each type of spoken error correction below?}

$$
\text { جُونه شما هر كدام از تصحيح اشتباهات شفاهى ذيل را ارزيابى مى نماييد؟ }
$$

Teacher: Where did you go yesterday?

$$
\text { ديروز شما كجار فتنيد؟ }
$$

Student: I go to the park.

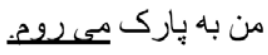

\section{Could you say that again?}

\begin{tabular}{|c|c|c|c|c|}
\hline $\begin{array}{c}\text { Very Effective } \\
\text { خيلى موثر }\end{array}$ & $\begin{array}{c}\text { Effective } \\
\text { موثر }\end{array}$ & $\begin{array}{c}\text { Neutral } \\
\text { خنتى }\end{array}$ & $\begin{array}{c}\text { Ineffective } \\
\text { بى اثر }\end{array}$ & $\begin{array}{l}\text { Very Ineffective } \\
\text { خيلى بـى اثر }\end{array}$ \\
\hline
\end{tabular}

$$
\text { T أ. مى تو انيد دوباره آن را بكوييد؟ }
$$

13. I go? (Repetition: The teacher highlights the student's gram-

\begin{tabular}{|c|c|c|c|c|}
\hline $\begin{array}{c}\text { Very Effective } \\
\text { خيلى موثر }\end{array}$ & $\begin{array}{c}\text { Effective } \\
\text { موثز }\end{array}$ & $\begin{array}{c}\text { Neutral } \\
\text { خنتى }\end{array}$ & $\begin{array}{c}\text { Ineffective } \\
\text { بى اثز }\end{array}$ & $\begin{array}{c}\text { Very Ineffective } \\
\text { خيلى بى اثز }\end{array}$ \\
\hline
\end{tabular}
matical error by using intonation.)

rا ـ من مى روم؟ ( تكر ار : معلم به وسيله آهنگ جمله اشتباهات كر امرى دانش آموزان را برجسته مى كند.)

14. I went there yesterday, too. (Implicit feedback: The teacher does not directly point out the student's error but indirectly corrects it.)

\begin{tabular}{|c|c|c|c|c|}
\hline $\begin{array}{c}\text { Very Effective } \\
\text { خيلا موثر }\end{array}$ & $\begin{array}{c}\text { Effective } \\
\text { موثر }\end{array}$ & $\begin{array}{c}\text { Neutral } \\
\text { خنت }\end{array}$ & $\begin{array}{c}\text { Ineffective } \\
\text { A }\end{array}$ & خery Ineffective \\
\hline
\end{tabular}

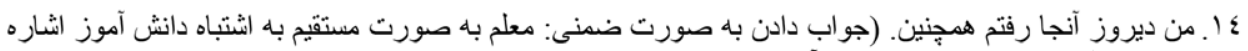

نمى كند بلكه به صورت غير مستقيم آنرا اتصحيح مى نماييد.) 
15. "Go" is in the present tense. You need to use the past tense "went" here. (Explicit feedback: The teacher gives the correct form to the student with a grammatical explanation.)

\begin{tabular}{|c|c|c|c|c|}
\hline $\begin{array}{c}\text { Very Effective } \\
\text { خيلى موثر }\end{array}$ & $\begin{array}{c}\text { Effective } \\
\text { موثر }\end{array}$ & $\begin{array}{l}\text { Neutral } \\
\text { خنتى }\end{array}$ & $\begin{array}{c}\text { Ineffective } \\
\text { بى اثز }\end{array}$ & $\begin{array}{l}\text { Very Ineffective } \\
\qquad \begin{array}{|l}\text { خيلى بى اثز }\end{array}\end{array}$ \\
\hline
\end{tabular}

16. Yesterday, I... (Elicitation: The teacher asks the student to correct and complete the sentence.)

17 . ديروز من ...(فر اخو اندن: معلم تقاضا مى كند كه دانش آموز اشتباه را تصحيح و جمله را كامل كند.)

\begin{tabular}{|c|c|c|c|c|}
\hline Very Effective & Effective & Neutral & Ineffective & Very Ineffective \\
\hline خيلى موثر & موثر & خنتى & 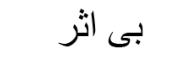 & خيلى بى اثز \\
\hline
\end{tabular}

17. Really? What did you do there? (No corrective feedback: The teacher does not give corrective feedback on the student's errors.)

\begin{tabular}{|c|c|c|c|c|}
\hline Very Effective & Effective & Neutral & Ineffective & Very Ineffective \\
\hline خيلى موثر & موثر & خنظى & بى اثر & خيلى بى اثر \\
\hline
\end{tabular}

18. How does the verb change when we talk about the past? (Metalinguistic feedback: The teacher gives a hint or a clue without specifically pointing out the mistake.)

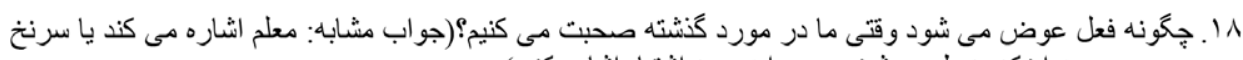

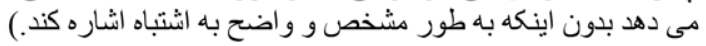

\begin{tabular}{|c|c|c|c|c|}
\hline $\begin{array}{c}\text { Very Effective } \\
\text { خيلى موثر }\end{array}$ & $\begin{array}{l}\text { Effective } \\
\text { موثز }\end{array}$ & $\begin{array}{l}\text { Neutral } \\
\text { خنتى }\end{array}$ & $\begin{array}{c}\text { Ineffective } \\
\text { بى اثر }\end{array}$ & $\begin{array}{l}\text { Very Ineffective } \\
\text { خيلى بـى اثر }\end{array}$ \\
\hline
\end{tabular}


19. I went to the park. (Recast: The teacher repeats the student's utterance in the correct form without pointing out the student's error.) 9 1. من به بارك رفتم. ( تصحيح بى جون و جهر ا: معلم جمله دانش آموز را با فرم درست آن تكرار مى كند بدون اينكه

به اشتباه دانش آموز اشاره كند.)

\begin{tabular}{|c|c|c|c|c|}
\hline Very Effective & Effective & Neutral & Ineffective & Very Ineffective \\
\hline خيلى موثر & موثز & خنتى & بى اثر & خيلى بى اثر \\
\hline
\end{tabular}

\section{The following person should treat students' errors.}

$$
\text { مو افقم كه فرد ذيل اشتباهات ر ا تصحيح كند. }
$$

\section{Classmates}

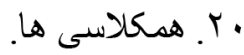

\begin{tabular}{|c|c|c|c|c|}
\hline Strongly Agree & Agree & Neutral & Disagree & Strongly Disagree \\
\hline به شدث مو افق & مو افق & خنثي & مخالف & به شدث مخالف \\
\hline
\end{tabular}

\section{Teachers}

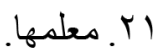

\begin{tabular}{|c|c|c|c|c|}
\hline Strongly Agree & Agree & Neutral & Disagree & Strongly Disagree \\
\hline به ثدث مو افق & مو افق & خنثي & مخالف & به شدت مخالف \\
\hline
\end{tabular}

22. Myself

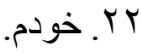

\begin{tabular}{|c|c|c|c|c|}
\hline Strongly Agree & Agree & Neutral & Disagree & Strongly Disagree \\
\hline به شدت مو افق & مو افق & خنتى & مخالف & به شدت مخالف \\
\hline
\end{tabular}

\section{Demographics}


Please circle the information that applies to you. Make sure to mark only one.

لطفا دور اطلاعاتى كه از شما خو استه شده است دايره بكثيد. اطمينان حاصل كنيد كه فقط يك مورد را علامت يزنيد.

\section{Gender}

بr.

\begin{tabular}{|c|c|}
\hline Male & Female \\
در & $\dot{0 j}$ \\
\hline
\end{tabular}

24. Your first language

צ ع. زبان اول شما.

\begin{tabular}{|c|c|c|c|c|}
\hline $\begin{array}{l}\text { Korean } \\
\text { كرهاى }\end{array}$ & $\begin{array}{c}\text { Japanese } \\
\text { زاينى }\end{array}$ & $\begin{array}{l}\text { Chinese } \\
\text { جينى }\end{array}$ & $\begin{array}{l}\text { Spanish } \\
\text { اسبانيايبى }\end{array}$ & $\begin{array}{l}\text { Other: } \\
\text { زبان ديكر }\end{array}$ \\
\hline
\end{tabular}

25. How long have you been studying English?

$$
\text { 0ץ. جه مدت در حال مطالعه زبان انكليسى بوده ايد؟ }
$$

\begin{tabular}{|c|c|c|c|}
\hline $\begin{array}{l}1 \text { year } \\
\text { يك سال }\end{array}$ & $\begin{array}{l}\text { 2-5 years } \\
\text { دو تا ينتج سـال }\end{array}$ & $\begin{array}{l}\text { 6-9 years } \\
\text { شُ تا نه سال }\end{array}$ & $\begin{array}{l}\text { More than } 10 \text { years } \\
\text { بيشتر از ده سال }\end{array}$ \\
\hline
\end{tabular}

26. What is your speaking or listening class level?

ب ب. سطح كلاس مكالمه يا شنيدارى شما جِيست؟

\begin{tabular}{|c|c|c|c|c|}
\hline $\begin{array}{c}\text { Beginning } \\
\text { مقدماتى }\end{array}$ & $\begin{array}{l}\text { Intermediate low } \\
\text { يايين تر از متوسطه }\end{array}$ & $\begin{array}{l}\text { Intermediate } \\
\text { منوسطه }\end{array}$ & $\begin{array}{l}\text { Intermediate high } \\
\text { بالا تر از متوسطه }\end{array}$ & $\begin{array}{c}\text { Advanced } \\
\text { يشير فته }\end{array}$ \\
\hline
\end{tabular}

